\title{
My life in the law
}

Shirley Smith

As a small girl, I grew up knowing that my father was a lawyer, a barrister who argued cases in court. I used to ask, running out to meet him, "Daddy, did you win your case today?" He always did, of course. At the age of 40 he was appointed to the Supreme Court Bench. He used to come home to lunch every day, and would sometimes tell us of a case he'd been trying. My father was always a good raconteur, and I was fascinated. "Daddy", I said, "I'd like to be a lawyer when I grow up." "Oh no," he said, "it is no job for a lady, you get involved in far too sordid things."

Uncharacteristically, I didn't question this prohibition, and never gave the law another thought, until years later. After taking a Classics degree at Oxford, lecturing back in New Zealand, marrying and finding myself in New York, the wife of the Secretary-General of the New Zealand Delegation to the United Nations, I attended a lecture on the Status of Women Commission, given by a member of that Commission, a woman lawyer. It was not what she said that won me to the law - I hardly took in a word - it was the appearance on the platform of this young woman, trim in a black suit. A woman lawyer. If she can do it, I said to myself, so can I.

When on our return to New Zealand, I broached the idea. No-one approved. Not my father, my husband, lawyer friends. No-one. Yet I summoned up the courage and enrolled in law without telling anyone. It was so easy then - only 2, 3 or 4 guineas for a year's lecture course in any one subject, depending on how many lectures were given in a week and 2 guineas Students Association fee. Having cast the die, I was relieved to find that all my critics accepted my new status as a law student and applauded my progress as I passed the examinations.

There were hardly any women in the Law School then. It was 1952. By the end of the year I was 36. Alison Alexander was in Roman Law with me, Shirley Robson (now Parr) was finishing. Shirley Sunley was there too; I remember the three Shirleys. Whether Paddy West-Walker was enroled in 1952, I am not sure; she was in 1953, as I have reason to remember. The only sexist problem that we were warned about was Professor McGechan's customary exclusion of women from one of his lectures. I was determined to resist this exclusion, but I did not have the opportunity, for alas, Professor McGechan was earlier killed in an aircrash at Singapore. My best coup, in this line, was when, in a Legal Ethics lecture, we were warned against chatting about our cases over dinner at home "with the little woman". I rose and asked if this stricture applied equally to "the little man". This brought the house down.

This was Shirley Robson's last year, and as it was the first time a woman had graduated for many years, the few women students, customarily excluded, were invited to attend the Law Faculty Club's annual dinner, traditionally held on the night of the last exam. I went. It was in a hotel, and Shirley asked the women to join her in predinner drinks in a distant corner of the lounge. Although it was impolite to Shirley, I 
refused to be segregated. Looking around for someone among the men to talk to, I settled on Don Inglis, now a Family Court Judge, and fortunately he was amenable.

Never shall I forget that dinner. The air was blue and the behaviour drunken. One senior practitioner gave tongue to a degree of lewdness that delighted the male students and led me to swear to myself, "Never again". But I had not foreseen the counterproductive activity of next year's committee. Towards the end of the year, when everyone was swotting for finals, a notice went up on the board: "Women students will not be admitted to the dinner" (or words to that effect). Up went my hackles - and a lot of other people's as well. They said to me "you must take out an injunction". I went to see the Dean of the Faculty. He laughed, and said, "exhaust your remedies first, try calling an SGM." So I did.

I went round the law offices (most students then were employed during the day: lectures were early and late) enlisting support from those I thought likely to be sympathetic. John Maclean and Graham Hubbard agreed to propose and second a motion requiring the dinner to be open to all students. Jack Lewin and Jimmy Winchester were then mature students: they were on side and agreed to speak in support. There was a good deal of irritation at having an SGM thrust upon the Faculty just before the final exams. This may have helped rather than hindered the cause. Who knows? At the meeting I restricted myself to a speech which I tried, reasonably successfully, to make as light and funny as possible, though I did point out that Bible Class students, identifiable by their lapel pins, were not excluded, they were free to exclude themselves: all that women were asking was the same freedom. We won, and I got the distinct impression that I was not popular with the President.

After my last exam, which was also the last exam of the year, I was about to relax, when I suddenly remembered that it was also the night of the dinner. I had no idea whether any of the other few women intended to go, but I thought, I must go, or they'll lynch me. So I turned up. I was the only woman present. It did not bother me in the least. It was so much easier for me than it would have been for any of the others. I was older, married, had studied and lived abroad and had some experience of life in the world: besides, I had always regarded men as people.

There was no further attempt to exclude women while I was a student, but I am sorry to say that when I came back, a couple of years later, to lecture, the ban was back. It was quite easy, this time, to get the rule reversed. Some of the men, however, still found it odd for women to appear at social functions. Going to a Faculty Club stein evening, I encountered a young man leaving as I was entering, who fell about in exaggerated horror, crying "What! do I see a woman?" As I had been used to drinking in pubs in mixed company in England, I found it odd, if not barbaric. And at times, at the dinner, efforts were made to segregate the women, still in a very small minority, at a separate table and provide them with wine, not beer, which was the standard drink. We managed to frustrate these manoeuvres, with the help of several sympathetic young men who changed seats with us.

What I found quite extraordinary was the change in behaviour at the dinners after women were admitted. I had stressed, in my speech, that we were not asking them to 
change anything: that if they did not enjoy the occasion, women, like Bible Class students, would not attend. They did not accept this invitation to shut us out, they sobered up. A good thing, no doubt, but psychologically strange.

Having reached what in those days were the final four subjects, Constitutional and International Law, Conflict of Laws and Jurisprudence, I decided that it was time I learnt something about office procedure and practice. I asked my friends Keith Matthews and Nigel Taylor if they would take me on as a law clerk. They were engaged in reviving the firm that had been Duncan and Hanna. Mr Hanna had been appointed to the Magistrates Court Bench, and Mr Duncan had retired, unfortunately not before he had largely lost his memory. The firm was now Duncan, Matthews and Taylor and Mathews and Taylor had quite a task in hand. They agreed that I could come and learn the ropes, on an hourly basis, so that I was free to have time off if my small daughter were ill, or in school holidays, while they were free to tell me if there was no work for me. It was an excellent arrangement for me, especially as I don't recall ever being told there was no work for me, although I took time off whenever I needed to. Jim Thomson and Brian Harvey were law clerks with me in that firm at one time or another and very pleasant they were to work with.

Because I now had a job and still had a flat, a husband and a daughter to look after, I took only two of the final four subjects in each of two years, finishing at the end of 1956. When I graduated in 1957, my father, as Chancellor of the University of New Zealand, capped me in the Wellington Town Hall and my small daughter presented me with a bouquet as I came down the steps from the platform. This was in the days before mass admissions, and I was admitted as barrister and solicitor by my father's old friend, Mr Justice Stanton, in the presence of my father and my husband.

Thereafter I continued with the firm during the rest of 1957 and 1956, making some appearances in the Magistrates Court and once or twice in the Supreme Court as a junior. My most notable appearance was for a union against its secretary, who had embezzled union funds. Neither Keith nor Nigel wished to appear, as they had both been friendly with the secretary before his sins found him out. He pleaded guilty, and I appeared only on the question of what restitution he could afford to pay. My "curly questions" earned me a report, with photograph, in a local tabloid newspaper.

The next change in my career came when I was asked to lecture at Victoria, first in Roman, and then Constitutional Law. One of the extra jobs I had during my time at Victoria was to be the first editor of the Victoria University of Wellington Law Review, which began its life as an unpretentious cyclostyled collection of essays by the students. Throughout my two years as a lecturer, I had constantly been asked by my father when I was going to get down to real work. In spite of the fact that he was now Chancellor of the University of New Zealand, and had been for many years on Victoria's Council, he did not want me to settle into "the ivory tower", as he called it. He told me that I should "earn my spurs in the heat and dust of the forum", a mixed metaphor which I understood to mean that I should return to the practice of the law, particularly in the courts.

As I was then approaching the age of 45 , rather late for a near-beginner, I decided that I must forsake the hill for the town, and began to look for an office. Keith and 
Nigel had let me keep my little room in their office, at an absurdly low rent, while I was lecturing, and, as I could not find anything else suitable, they agreed that I could start my own practice under their roof. So I began with my old secondhand portable typewriter, and an extension from the firm's telephone system. My rent was not increased. I do indeed owe a great deal to Keith and Nigel.

The old office had many charms. We were upstairs but only one short flight. Below was the best fish and chip restaurant in Wellington, an excellent newsagents, run by a friendly couple who became clients of mine. The central part of the office, where the typists sat at their desks, had an old-fashioned free-standing stove, which provided splendid heat in winter and a flat top on which one could heat soup. Perhaps Dickensian, but it had a charm that no modern office has.

Fortunately I could type, but unfortunately, for a long time, I had nothing to type. I found to my chagrin, that $I$ had to put in a monthly audit report advising the Law Society that I had nil, nil, nil in my trust account. I would rather have kept it quiet. I survived, of course, because I did not have to pay my own living expenses, and could pay practising fees, printing, rent and suchlike expenses from my university salary savings. I also had a very small private income, from which I had paid my university fees.

As far as I can remember, my first instructions came from the Wellington Family Planning Association. I drew up their Rules and incorporated them. Very early, I had my first matrimonial case, which involved custody as well as divorce. It was difficult and testing, but we won through. One complaint of the wife's that I shall never forget "He required me always to wear the colours of the BVM". "The BVM?" "The Blessed Virgin Mary, red and blue", she said.

Matrimonial cases, however, took some time to build up and I was glad. Although a feminist from my earliest years, I did not want to be typed as a "woman's lawyer". Help came from an unexpected source. When I had been lecturing, we had one extramural student who persisted. I do not remember another who ever sent in even one opinion. The persistent one was Byron O'Keefe, a married man who was an officer of the Crown Lands Department in Napier. He used to come to Wellington and sit in on lectures for one week in the middle of the winter term, and he was ecstatic about the experience how he envied the youngsters who could attend lectures all year! He took his LLB, of course, and then his Masters at Auckland, having been transferred there by his Department, and later became a lecturer and a Professor in the Law School at Auckland: and has also doctorates - earned degrees - from more universities world-wide than I can tell you. At this earlier stage, he felt that he had had more help from Don Inglis (by then a lecturer) and from me than from anyone else; and he rewarded us by sending us clients, first from Napier and then from Auckland, for me to act as solicitor on the record and Don to act as counsel. He also sent me clients for solicitor's work, one notable one being a farmer who wished to buy more land than the restrictive legislation of the time allowed him to own individually. I was instructed to set up a 10-man company. The legislators apparently thought that the need to rally nine stooges, happy to hold only one share each, would frustrate the farmer's intention to acquire more land. My client, however, had a large and obliging extended family. 
I was delighted. My father had specialised in company law, and I thought "I'm away" and dashed off and bought Anderson on Company Law. This job involved driving up to Napier, meeting my unusual and interesting client and his relations, and brought me a good deal more work, more visits to Napier and some acquaintance with the profession there, who did not appear to resent my poaching on their territory. This may have resulted from the known character of the clients sent me by Byron.

Another Napier client was not exactly referred by Byron, although it was through Byron that he had heard of me. After five o'clock one evening, when everyone else had gone - by this time I had staff - and I was winding up the day's work, the door burst open and in rushed a human hurricane. He'd driven down from Napier at top speed without prior notice of any kind and throwing a mass of papers on my desk, demanded attention forthwith. Intrigued, I sat and listened. And acted. I had little time to file his appeal against a matrimonial property decision given in the Supreme Court at Napier. The learned judge had plainly erred in law. The Court of Appeal agreed, but pointed out that the judge could have, if asked, given the wife a far greater share of the husband's property than he had, and wisely advised an adjournment for settlement. If the Court of Appeal referred the case back to the Supreme Court for rehearing, they said, in effect, that the husband could be taken to the cleaners. I had no doubt that they were right, but asked for time to take instructions. My client, however, was adamant: if he was entitled to judgment, judgment he would have. Victory he would have, he did not care if it was Pyrrhic. Not that he was persuaded that it would be. So I took judgment for him, and then set about winning what was, in the sphere of persuasion, my most famous victory. It took weeks, months, while the other side held back from setting the case down for rehearing, but I persuaded him to settle. Fellow practitioners in Napier could not believe it - they asked me how on earth I had done it!

By the time I persuaded my Napier client to settle, I was fairly well established. After a very slow start, I found that happy clients brought more clients, and the practice grew exponentially. This experience made me quite sure that the only advertising the legal profession needs is word of mouth; and the fact that after the initial splurge when the prohibition on advertising was lifted, you now rarely see legal advertisements, confirms my view.

In my early days, I was kept afloat by requests from Olive Smuts-Kennedy to take over her client, the College Debt Collecting Agency, while she was overseas or otherwise unable to act. I collaborated with the College office staff twice, for several months each time. I knew nothing whatever about debt-collecting, and the College staff, with whom I had a happy relationship, knew little more. We used to pore over "the Bible", as we called it, Wily's Magistrates Court Practice. Part of the job was to sign huge piles of Plaint Notes, and I would sit, at the end of the day, signing and signing as my signature grew more and more illegible.

My previous court experience, when employed by Duncan, Matthews \& Taylor, was mostly confined to being sent off to get adjournments. Before reform of the system, years later, by the Chief Justice, endless hours were wasted in lengthy battles over adjournments. When I first went off to court, nervously, I was encouraged by Nigel, 
who laughed and said "It's very difficult to lose an adjournment." And so it was. Even "final" adjournments were rarely final.

Of course I made mistakes, but I learnt by experience. I found magistrates tactfully helpful and do not recall any practitioners taking advantage of my inexperience. One expression of disapproval, and one only, I remember. While we were standing around in the No 2 Court, a fairly senior man attacked me, unpleasantly, for using my own name and not my husband's. "Are you ashamed of him?" he asked. A year or so later I rang to offer him my support. It was amusing how apprehensive he sounded when he answered the telephone. I had inherited a client of his who was accusing him of shocking dereliction of duty. I had spent a whole evening putting together the vast, disordered mass of papers the client had tossed on to my desk, and it had become obvious to me that he had gone far beyond the call of duty at his own expense, to help this client. We became good friends.

The only sexual discrimination I ever encountered in the legal profession was in the social sphere. Of course I avoided the discrimination of which women lawyers still complain, of being overlooked for promotion or partnership, by never offering my services to a firm since my first employment with Duncan, Matthews \& Taylor, after I came down town from the University. At that time, qualified women were very rare. Miss Ongley practised on her own, Miss Julia Dunn was a partner in her family firm, Mrs Marjorie Taylor a partner in her husband's firm in Petone, but they were never seen outside their offices. I was not aware of any woman law clerks, professionals, that is. (Clerks and typists were also law clerks). I had no intention, especially at my advanced age, of applying and being turned down. I was not going to give a man the opportunity to treat me so, and I was lucky, that in my circumstances, I did not have to. Hence I set up my shingle on my own, and always remained a sole practitioner. It gave me a great deal of freedom, especially in that I had no responsibility for the income of a partner. I could take what cases I liked, whether or not they covered costs. In the social sphere, however, it was very different. The attitudes of the men of the Law Faculty Club were continued in the higher ranks of the profession. Women were not admitted to the dinners, either of the Wellington District Law Society or the New Zealand Law Society, at its triennial conferences. I set out to alter this.

So long after, I do not recall the steps I took to alter the Wellington Society's attitude. Many of the most senior practitioners were friends of my father's, or remembered him well on the Bench (he had retired in 1948) and in this connection my age was no disadvantage. One of these men was Dave Perry, who was most kind and welcoming to me. He had gone on record, extolling lawyers as men of principle, and I tackled him on this. "How can you not see the principle that all members of the Society must be eligible for the dinner?" I said "sex is irrelevant."

Reluctantly, I think, the Society had to recognise the principle, and, in 1959, women were finally invited on equal terms. Again, as with the Law Faculty Club dinner, at the last moment I realised that the dinner was to be that night, and I had not canvassed any of the other women. There was still only a handful of us. There was not time to ring around, and again I thought, after campaigning, I'll have to go, or they'll be out for my blood. As usual, I was late, and arrived when they were all seated. It is hard 
to imagine now, but the whole company were accommodated at tables forming an incomplete semi-circle, the side tables placed at a wide angle to the top table, which was very long, the hole covered by white tablecloths concealing any gaps. (I can see it as if it were yesterday.) No other woman was present. One seat was left, at the end of the table on my left; so I took it and sat down.

I don't remember whom I sat next to, or what conversation there was, but I shall never forget the speeches. There were far more speeches in those days than now, and every speaker made some reference to my presence; I was beyond caring what anyone thought of me, and when the comment was favourable I shouted "Hurrah!" and when the reverse, "Boo!" There was no repercussion, except that as we stood around afterwards having post-prandial drinks, a number of the senior practitioners congratulated me on my courage. I smiled and thanked them, but it hadn't taken any courage at all: I could not have done otherwise.

After that, alas, they resiled from principle again, inviting unqualified women on the Law Society staff. It seemed that they were hypnotised by the sexual divide. At least they were not hypnotised to the extent of inviting wives. That was reserved for the New Zealand Law Society. There was, however, one further hiccup before the Wellington Law Society settled down to accepting women as full members on social occasions.

When Earl Warren, Chief Justice of the United States, visited in July 1961, the Wellington Law Society decided to hold the dinner at the Wellington Club, which was not only a "male-only" stronghold, it could not accommodate all who might want to attend. I knew that, while women could not belong to the club, they could attend social occasions, if taken by a member. I had been my father's guest. I learned, however, on the grapevine, that any applications from women were to be set aside until the complement was full, and then they were to be told "Sorry, there was no room for you." I rang up and asked the President, simply, "Is there any point in my applying?" (I had in fact applied at once, as I wanted to hear Earl Warren.) There was a short pause, and then he said, "Of course, Shirley." We were then informed, by circular notice that attendance at the dinner would be limited to partners and sole practitioners, because of the limited accommodation. Again I was the only woman present. Ironically, the Chief Justice's attention was drawn, in the President's speech, to the presence of a woman lawyer as evidence of Wellington's progressiveness.

When I read the programme for the New Zealand Law Society's 1969 Conference, I found that there was to be a dinner, and a wives' dinner; and there was to be picnic trip for the wives. As there was no mention of husbands, I wrote to the Waikato society, the organizers, asking whether my husband should attend the dinner, as a man, or the wives' dinner, as a spouse? A reply came from Ross Jansen (now Sir Ross) whom I knew from Victoria days. He was one of the young men coping with the heavy end of organising the conference (we did not then hand the job over to professional organisers). He wrote that my letter had caused consternation to the committee, who were "a lot of old crustaceans": he said that he agreed with me, but he did not know, at this stage, what would be done. I never had an official reply. What was done was that two dinners were held, in the old Bath House, on different nights, both mixed, members, wives, 
secretaries and all. An improvement, no doubt, but I was baffled by the inability of men of law to grasp what appeared to me to be a very simple principle.

I find it sad that women in the profession, for whose full status (without regard to gender) as lawyers I fought, have now abandoned the principle, in setting up a Women Lawyers' Society. My hope is that, with this year more women than men studying law, the Women Lawyers' Society will before long be seen to be the aberration it is.

The dinner which gives the greatest pleasure to look back on was the Wellington dinner in 1975. My husband had died at the end of September, the dinner was held on 10th October: it was also my birthday, although only I was conscious of that. Once more I was late; apart from my normal unpunctuality, I could not find a parking place. Everyone was seated when I arrived. As I entered the room, they all rose as one and stood until I was seated. A seat was found for me beside old friends. I was moved almost to tears, and shall never forget the occasion, both for the great courtesy shown me and for the fact that that dinner was for members only, without regard to sex.

Through the 1960s, my work built up steadily. With my first real profit, I bought what was then a state of the art typewriter, an Imperial 70. I was pleased that my work was varied. I had cases in contract, tort, building disputes, immigration, conveyancing, tenancy, paternity, divorce and domestic law generally, and later, matrimonial property and crime. I also took many cases arising from traffic accidents (my clients were usually uninsured), I drafted wills, wound up estates, incorporated societies and even formed companies - small ones. It was young men who came to me for this purpose. The first time, after taking instructions, I asked my two tall young clients, "Why did you come to me?" "Oh, we found your name in the Yellow Pages." "But there are a lot of other solicitors there," I said, "Why me?" "Oh", they said, "You were the only one we could tell was a woman." (I have always listed as "Shirley Smith", others at that stage were using only initials.) "But why", I asked, "did you want a woman?" "Because we thought you would look after us", they said.

I have always had plenty of male clients, even in matrimonial cases. At the 1969 Law Society Conference, I was asked to be one of the commentators following the address by Don Inglis on the new Domestic Proceedings Act. I told the packed auditorium that as I had men as well as women clients in this field, I could tell them that "marital monsters come in both sexes." This drew a perhaps startled shout of laughter. I have always believed that women should be treated equally with men and have equal opportunities of all kinds, but I could never accept that, a priori, women were always in the right and men in the wrong. I have been asked by women friends "You would never act for a man charged with rape, would you?" to which the principled answer must always be, "Yes, I would." To begin with, he is not guilty because he is charged: if he is guilty, he is still entitled to have a plea made for him in mitigation. I have acted for men charged with rape, and while I hate the crime as much as anyone, I cannot hate the criminal. What one learns from probation reports (now pre-sentence reports) teaches one that society made that criminal. Society's rage against criminals is a reflection of its refusal to face and accept its own responsibility. 
Many of my male clients have both wanted and rejected a woman's care. Sitting across the table from me, they might say "Of course, I could never be told what to do by a woman." I would look at them quizzically and raise my eyebrows, and some of them would realise the absurdity. A prime case was an explosive Yugoslav who belatedly wanted access to his little daughter, of whom he had taken no notice since birth. I pulled no punches in talking to him and advising him, and he would fling out of the office in a rage, banging the door. My secretary said "He'll be back", and he always was, until he left New Zealand.

I realise that I am known now mainly as counsel for the gangs: this is to some extent a misconception, as there are many gangs that I have never acted for. This was a comparatively late development. The first gang was the Wellington Black Power. We had a very successful run, but although our clients were mostly in well-paid jobs, concreting and demolition work, they never paid. Finally, one case, in which the boy got off, I took this issue up with the gang leader. He said he would speak to the boy. He did, rang me back and said, "Shirley, he's got a point: he said 'the charge was dismissed, I've done nothing wrong, why should I pay?'" Many of them never really took in that I had to pay overheads before I could pocket any of their money. One young lad, years later, listened to me explaining that I had to pay rent, staff, postage, telephone and so on with looks of growing amazement and said "But isn't it all provided?" No doubt he was used to dealing with government departments.

My representation of the Black Power boys came to an end when my assistant fielded a call from the gang leader, asking us to take another case. She exploded: "Don't you dare send us any more, none of your boys has ever paid". I meant to rescind this unauthorised rejection, but never got round to it.

Later I appeared for several members of the Porirua Mongrel Mob. I think it arose from a legal aid assignment. I battled for those boys as (they told me) no-one had ever done before. I still enjoy the memory of my first case, for a young Mob member, for whom I subpoena'ed a reluctant barman. The barman gave his evidence-in-chief well enough but it was the effect of a savage cross-examination that turned him into a superb witness for the defence, he was so furious that his truthful evidence was doubted, indeed rejected by the prosecuting sergeant. He followed us out after the charge was dismissed, and shook hands with us both, beaming at having enabled justice to be done.

My name must have been good with the Mob, because on the day in October 1980, when there was an affray between the Mongrel Mob and the Black Power, the President, Big Charlie, whom I had never met, rang me and said "Shirley, there are 15 of my boys in the Police cells at Central, will you look after them?" So down I went and the cry went up "Shirley, your children need you!" How could one resist that? After this I was recognised as the Porirua Mob's lawyer. I had a very good run for them, though of course I did not always win. When we were waiting in the law library once for a jury to come back, a police officer burst out with "Do they ever pay you?" - to the shocked surprise of prosecuting counsel, who reprimanded the officer.

So many memories.... I could go on and on. I should perhaps mention the considerable practice I had for many years in both matrimonial property and paternity 
cases. The first category was largely on question of law, the second of evidence. In these cases I was in truth a women's lawyer: I don't think I ever acted for a man. In one matrimonial property case, my client found that the telephone wires (left unsealed when her husband had removed an extension telephone when he left home) were giving her news of a scam that her husband was fixing up with a friend on the other extension, to her disadvantage. She borrowed a cassette recorder, and had a full and clear record of the perjury that the miscreants intended to commit. It even included notice of vengeance that they intended to take on the wife's lawyer, namely, me. We were very principled, and settled only for what we thought we were entitled to get. I sometimes think that we were too principled. In a paternity case which I shall never forget, the mother had the clearest recollection of what had happened, of where it had happened and of unusual scars on the body of the alleged father and when she brought the little boy to Court with her, the likeness was overwhelming. The magistrate, however, refused to see the child, on the ground that a likeness was not evidence. Needless to say, counsel for the defendant strongly pressed this view. Fortunately, our other evidence was so good that there could be little doubt: if there was any, it vanished when I asked permission to require the defendant to remove his shirt, which he did, having no choice. These are only two of a number of cases which brought me great satisfaction.

In criminal law cases, there are no words so sweet in the ear to defence counsel as "Not Guilty", especially as they always come after a period of tension, which may be short, but is usually long. After these welcome words, in one case, when my client, a large and powerful member of the Mongrel Mob, and I emerged into the corridor, he enveloped me in a bearhug, observed by passing court staff. I have often been asked, how do you feel when you get someone off whom you know to be guilty? to which my answer is, I do not recall a case in which that happened; although I can remember cases in which clients I was sure were innocent were convicted.

I have acted for many Pacific Islanders, as well as my Maori clients. For many years, until I retired as a solicitor, I was Honorary Solicitor for the Cook Island Society. I incorporated the Wellington Branch and acted for it during the period when it was raising money to build its impressive hall on town belt land. I acted also for individual members. It was a very rewarding association, and I greatly admired the forthright, determined, reliable character of the Cook Islanders. I acted also for many Samoans. I remember a beautiful young man, who, on having just arrived, was given a cheque book by a bank: he proceeded to dance through Wellington, scattering this wonderful paper money far and wide, with no reference to what he had in his bank account. I saved him from the legal consequences by persuading the Police that the person who should be brought to account was the bank manager. For many years I was guardian angel to him and his subsequently acquired family and to his brothers as they arrived one after the other from Samoa. They still ring me up from time to time, just to say hello. Of the Samoans, however, I chiefly remember with admiration the women who worked all day in the home, with small children, and all night, in the hospitals as nurse-aids, or Government offices, cleaning, to keep their families afloat. No praise could be too great for them.

Towards the end of 1983, when the lease on my chambers had expired and Dunbar Sloane wanted my office for his own purposes, I decided not to open another office in 
town, but to limit myself to a criminal practice carried on from home. I arranged to meet my clients sometimes in town over coffee, but more often in and around the courts. That was where they expected to find me, anyway. I remember an indignant outburst "we've waited for you outside the Court for three days, and you didn't turn up!" They rarely used the telephone to make an appointment, and often I had to drive some distance to see them before a hearing or get them to find a witness for me.

I have given up my solicitor's certificate because I have so many other things that I must do and put in order before I die, which have been neglected during my long preoccupation with the law. I miss my clients, I miss the practice of the law, but perhaps it is time I gave up, because I doubt if I could accommodate myself to the changes. I love to research the law in the books, but now the library is deserted and the offices rely on computerised databases. I have no computer or fax machine, not even a word processor. What typing I do is still done on my old Imperial 70. The Dickensian old offices of the past are long gone, and I find the modern decor uncongenial. My day is past, but it was a good day. 